\title{
FAKTOR YANG BERHUBUNGAN DENGAN KEJADIAN HIPERTENSI PADA LANSIA DI POSYANDU LANSIA DI WILAYAH KERJA PUSKESMAS SIMPANG BAHJAMBI KABUPATEN SIMALUNGUN
}

\author{
Jon Piter Sinaga, Novi Silvia Vera \\ Institut Kesehatan Deli Husada, Jl. Besar No. 77 Delitua \\ e-mail : sinagajonpiter18@gmai.com
}

\begin{abstract}
The increasing prevalence of hypertension each year is a major problem in developing and developed countries. This research was conducted at the post of integrated service of elderly Working area public health center of Simpang Bahjambi, Simalungun Regency. The type of research is a descriptive correlation and using stratified random sampling technique the total sample is 88 respondents. Data were analyzed by using the chi-square test and multiple linear regression tests at $95 \%$ confidence. The results of this research show that there is no relationship between the habit of consuming alcoholic beverages with the incidence of hypertension. There was a significant relationship between age, gender, and family disease history. BMI, smoking, and stress with the incidence of hypertension in the elderly. From multiple linear regression tests, found that the most dominant variable correlated significantly with the incidence of hypertension for the elderly is the age factor. It is expected that the society to find information about hypertension disease for the elderly who expected the information is useful and can influence the change of elderly attitude in order to make efforts to control hypertension, besides that the elderly family also willing to make efforts of supervision on family members who suffer from hypertension.
\end{abstract}

Keywords: hypertension, elderly, age, smoking, stress

\section{PENDAHULUAN}

Meningkatnya prevalensi hipertensi setiap tahun menjadi masalah utama di negara berkembang dan negara maju. Berbagai perubahan fisiologis akibat proses penuaan akan dialami oleh lansia yang diantaranya memicu terjadinya hipertensi. Hipertensi adalah suatu gangguan pada pembuluh darah yang mengakibatkan suplai oksigen dan nutrisi yang dibawa darah terhambat sampai ke jaringan tubuh yang membutuhkannya. Kadar kolesterol total akan meningkat secara bertahap seiring dengan bertambahnya usia (Pithaloka, 2011).

Hipertensi juga merupakan faktor resiko utama untuk terjadinya penyakit kardiovaskular. Apabila tidak ditangani dengan baik, hipertensi dapat menyebabkan stroke, infark miokard, gagal jantung, demensia, gagal ginjal, dan gangguan pengelihatan. World Health Organization (WHO) memperkirakan hipertensi menyebabkan 9,4 juta kematian dan mencakup $7 \%$ dari beban penyakit di dunia (WHO, 2014).
Di Indonesia saat ini hipertensi merupakan tantangan besar, berdasarkan survey riset dasar kesehatan nasional (RISKESDAS) pada tahun 2013 hipertensi memiliki prevalensi yang tinggi, yaitu sebesar $25,8 \%$. Disamping itu pengontrolan hipertensi belum adekuat meskipun sudah banyak tersedia obat-obatan yang efektif (Depkes RI, 2013).

Kondisi ini dapat menjadi beban baik dari segi finansial, karena berkurangnya produktivitas sumber daya manusia akibat komplikasi penyakit ini, maupun dari segi sistem kesehatan. Bedasarkan data WHO pada tahun 2014 terdapat sekitar 600 juta penderita hipertensi di seluruh dunia. Prevalensi tertinggi terjadi di wilayah Afrika yaitu sebesar $30 \%$. Prevalensi terendah terdapat di wilayah Amerika sebesar 18\%. Secara umum, laki-laki memiliki prevalensi hipertensi yang lebih tinggi dibandingkan wanita. RISKESDAS pada tahun 2013 mencatat prevalensi hipertensi di Indonesia sebesar 25,8 \%, dengan prevalensi tertinggi terdapat di Bangka Belitung (30,9\%), diikuti Kalimantan Selatan (30,8\%), Kalimantan 
Timur (29,6\%) dan Jawa Barat $(29,4 \%)$ dan Sumatera Utara $(24,7 \%)$ (Depkes RI, 2013).

Hipertensi pada lanjut usia sebagian besar merupakan hipertensi sistolik terisolasi (HST), meningkatnya tekanan sistolik menyebabkan besarnya kemungkinan timbulnya kejadian stroke dan infark myocard bahkan walaupun tekanan diastoliknya dalam batas normal (isolated systolic hypertension). Isolated systolic hypertension adalah bentuk hipertensi yang paling sering terjadi pada lansia. Pada suatu penelitian, hipertensi menempati $87 \%$ kasus pada orang yang berumur 50 sampai 59 tahun. Adanya hipertensi, baik HST maupun kombinasi sistolik dan diastolik merupakan faktor risiko morbiditas dan mortalitas untuk orang lanjut usia. Hipertensi masih merupakan faktor risiko utama untuk stroke, gagal jantung penyakit koroner, dimana peranannya diperkirakan lebih besar dibandingkan pada orang yang lebih muda (Kuswardhani, 2007)

Menurut Gunawan dalam Pithaloka (2011) faktor dan penyebab terjadinya hipertensi antara lain : a). Faktor keturunan, seseorang akan memiliki kemungkinan lebih besar untuk menderita hipertensi jika orangtuanya penderita hipertensi. b) Ciri perseorangan, yaitu umur, jenis kelamin, dan ras. Umur yang bertambah akan menyebabkan terjadinya kenaikan tekanan darah. Tekanan darah pria umumnya lebih tinggi dibandingkan wanita. Data statistik di Amerika menunjukkan hipertensi pada orang kulit hitam hampir dua kali lebih banyak dibandingkan dengan orang kulit putih. c). Kebiasaan hidup, antara lain: Konsumsi garam yang tinggi. Berdasarkan data statistik diketahui bahwa hipertensi jarang diderita oleh suku bangsa atau penduduk dengan konsumsi garam yang rendah. Dunia kedokteran juga telah membuktikan bahwa pembatasan konsumsi garam (natrium) oleh obat diuretik (pelancar kencing) akan menurunkan tekanan darah lebih lanjut. Kegemukan atau makan yang berlebihan.

Selain itu penyebab hipertensi pada lansia juga disebabkan oleh perubahan gaya hidup dan yang lebih penting lagi kemungkinan terjadinya peningkatan tekanan darah tinggi karena bertambahnya usia lebih besar pada orang yang banyak mengkonsumsi makanan yang banyak mengandung garam. Di Indonesia, dengan tingkat kesadaran akan kesehatan yang lebih rendah, jumlah pasien yang tidak menyadari bahwa dirinya menderita hipertensi dan yang tidak mematuhi minum obat kemungkinan lebih besar (Seke, 2016).

Berdasarkan hasil penelitian Wahyuningsih (2013), Hipertensi pada lanjut usia berhubungan dengan usia, kebiasaan olahraga, obesitas dan tipe kepribadian, sedangkan faktor yang mempengaruhi hipertensi adalah usia, obesitas, kebiasaan olahraga, stress, tipe kepribadian serta stress merupakan faktor yang paling dominan mempengaruhi hipertensi pada usia lanjut. Hasil penelitian Arifin (2016), terdapat hubungan yang bermakna antara genetik, olah raga, dan tingkat stress dengan kejadian hipertensi pada lansia. Sedangkan jenis kelamin, obesitas, merokok, dan konsumsi alkohol tidak terdapat hubungan yang bermakna dengan kejadian hipertensi. Sedangkan hasil penelitian Siringo-ringo (2013), secara umum ada hubungan yang signifikan antara umur, riwayat keluarga, dan kebiasaan makan lemak jenuh dengan kejadian hipertensi.

Posyandu Lansia wilayah kerja Puskesmas Simpang Bahjambi Kabupaten Simalungun tersebar di 16 desa, masing-masing desa terdapat 1 posyandu lansia. Jumlah peserta lansia di posyandu lansia wilayah kerja Puskesmas Simpang Bahjambi Kabupaten Simalungun sebanyak 719 orang, berjenis kelamin laki-laki berjumlah 434 orang dan perempuan berjumlah 285 orang. Dari survey pendahuluan yang penulis lakukan, dari 10 lansia terdapat 3 orang lansia menderita hipertensi. Dari latar belakang di atas, maka penulis tertarik untuk melakukan peneliti tentang Faktor yang berhubungan dengan kejadian hipertensi pada lansia di Posyandu Lansia di Wilayah Kerja Puskesmas Simpang Bahjambi Kabupaten Simalungun.

\section{METODE}

Jenis penelitian yang digunakan adalah deskriptif korelatif dengan pendekatan cross sectional, dimana variabel independen dan variabel dependen di teliti pada waktu yang bersamaan. Penelitian ini dilakukan di Posyandu Lansia Wilayah Kerja Puskesmas Simpang Bahjambi Kabupaten Simalungun pada bulan April sampai dengan bulan Mei 2017. Dengan jumlah populasi sebanyak 719 orang. Sampel yang digunakan dengan menggunakan stratified random sampling atau disebut juga alokasi proporsional. Alokasi proporsional merupakan suatu metode untuk mengalokasikan sampel dimana ukuran sampel untuk setiap stratum 
sesuai dengan proporsi ukuran masing-masing stratum. Metode pengukuran data menggunakan kuesioner yang berupa sejumlah pernyataan tertulis. Analisa data dilakukan secara univariat, bivariat, dan multivariat

\section{HASIL DAN PEMBAHASAN}

\section{Analisis Univariat}

Setelah dilakukan penelitian mengenai faktor yang berhubungan dengan kejadian hipertensi pada lansia di Posyandu Lansia di Wilayah Kerja Puskesmas Simpang Bahjambi Kabupaten Simalungun Tahun 2016, maka diperoleh hasil sebagai berikut:

Tabel 1 Karakteristik Responden

\begin{tabular}{|c|c|c|c|}
\hline No & Variabel & $\mathbf{n}$ & (\%) \\
\hline \multirow[t]{3}{*}{1.} & Umur & & \\
\hline & a. 55-64 tahun & 37 & 42,0 \\
\hline & b. $\geq 65$ tahun & 51 & 58,0 \\
\hline \multirow[t]{3}{*}{2.} & Jenis Kelamin & & \\
\hline & a. Laki-laki & 58 & 65,9 \\
\hline & b. Perempuan & 30 & 34,1 \\
\hline \multirow[t]{4}{*}{3.} & Riwayat Penyakit & & \\
\hline & Keluarga & & \\
\hline & a. Positif & 75 & 85,2 \\
\hline & b. Negatif & 13 & 14,8 \\
\hline \multirow[t]{3}{*}{4.} & IMT & & \\
\hline & a. Obesitas & 33 & 37,5 \\
\hline & b. Tidak Obesitas & 55 & 62,5 \\
\hline \multirow[t]{3}{*}{5.} & Kebiasaan Merokok & & \\
\hline & a. Merokok & 40 & 45,5 \\
\hline & b. Tidak Merokok & 48 & 54,5 \\
\hline \multirow[t]{3}{*}{6.} & Konsumsi Alkohol & & \\
\hline & a. Mengkonsumsi & 8 & 9,1 \\
\hline & b. Tidak Mengkonsumsi & 80 & 90,9 \\
\hline
\end{tabular}

7. Tingkat Stress
a. Stress
$65 \quad 73,9$
b. Tidak Stress
$23 \quad 26,1$

8. Kejadian Hipertensi
a. Hipertensi
$52 \quad 59,1$
b. Tidak Hipertensi
$36 \quad 40,9$

responden tidak merokok sebanyak 48 orang $(54,5 \%)$, mayoritas tidak mengkonsumsi minuman ber-alkohol sebanyak 80 orang $(90,9 \%)$ dan mayoritas tingkat responden kategori stress sebanyak 65 orang $(73,9 \%)$, mayoritas responden mengalami kejadian hipertensi sebanyak 52 orang (59,1\%).

\section{Analisis Bivariat}

Tabel 2 Hubungan Antar Faktor Hipertensi

\begin{tabular}{|c|c|c|c|c|c|}
\hline \multirow[t]{3}{*}{ No. } & \multirow{3}{*}{$\begin{array}{l}\text { Variabel } \\
\text { Independen }\end{array}$} & \multicolumn{2}{|c|}{$\begin{array}{c}\text { Kejadian } \\
\text { Hipertensi }\end{array}$} & \multirow[t]{3}{*}{ Nilai P } & \multirow{3}{*}{$\begin{array}{c}\text { OR } \\
(95 \% \mathrm{CI})\end{array}$} \\
\hline & & Ya & Tdk & & \\
\hline & & $n$ & $n$ & & \\
\hline \multirow[t]{3}{*}{1.} & Usia & & & & \\
\hline & a. 55-64 tahun & 12 & 25 & 0,000 & 7,576 \\
\hline & b. $\geq 65$ tahun & 40 & 11 & & $(2,905-19,759)$ \\
\hline \multirow[t]{3}{*}{2.} & Jenis Kelamin & & & & \\
\hline & a. Laki-laki & 37 & 21 & 0,212 & 1,762 \\
\hline & b. Perempuan & 15 & 15 & & $(0,721-4,307$ \\
\hline \multirow[t]{3}{*}{3.} & Riwayat Peny. Keluarga & & & & \\
\hline & a. Positif & 50 & 25 & 0,001 & 11,000 \\
\hline & b. Negatif & 2 & 11 & & $(2,263-53,473)$ \\
\hline \multirow[t]{3}{*}{4.} & IMT & & & & \\
\hline & a. Obesitas & 24 & 9 & 0,044 & 2,571 \\
\hline & b. Tidak Obesitas & 28 & 27 & & $(1,014-6,522)$ \\
\hline \multirow[t]{3}{*}{5.} & Kebiasaan Merokok & & & & \\
\hline & a. Merokok & 29 & 11 & 0,020 & 2,866 \\
\hline & b. Tidak Merokok & 23 & 25 & & $(1,170-7,018)$ \\
\hline \multirow[t]{3}{*}{6.} & Minuman Alkohol & & & & \\
\hline & a. Mengkonsumsi & 4 & 4 & 0,583 & 0,667 \\
\hline & b. Tidak Mengkonsumsi & 48 & 32 & & $(0,155-2,860)$ \\
\hline \multirow[t]{3}{*}{7.} & Tingkat Stress & & & & \\
\hline & a. Stress & 43 & 22 & 0,023 & 3,040 \\
\hline & b. Tidak Stress & 9 & 14 & & $(1,138-8,121)$ \\
\hline
\end{tabular}

Berdasarkan tabel 2 di atas diketahui proporsi kejadian hipertensi pada responden mayoritas 40 orang mengalami kejadian hipertensi pada usia $\geq 65$ tahun $(76,9 \%)$, mengalami kejadian hipertensi minoritas 12 orang pada usia 55-64 tahun (23,1\%). Hasil uji chesquare menunjukkan ada hubungan yang signifikan antara usia dengan kejadian hipertensi $(p=0,00)$. Dari analisis Odds Ratio (OR) diketahui Usia $\geq 65$ tahun 7,5 kali lebih beresiko menderita hipertensi.

Berdasarkan jenis kelamin, proporsi kejadian hipertensi mayoritas 37 orang pada jenis kelamin laki-laki $(71,2 \%)$, dan pada jenis kelamin perempuan yang mengalami kejadian hipertensi hanya 15 orang $(28,8 \%)$. Hasil uji che-square menunjukkan tidak ada hubungan antara jenis kelamin dengan kejadian hipertensi $(p=0,212)$. Dari analisis Odds Ratio (OR) diketahui kejadian hipertensi pada laki-laki hanya 1,7 kali lebih beresiko menderita hipertensi.

Berdasarkan riwayat penyakit keluarga, proposi kejadian hipertensi mayoritas 50 orang 
pada riwayat penyakit keluarga kategori positif $(96,2 \%)$, dan riwayat penyakit keluarga kategori negatif 5 orang $(3,8 \%)$. Hasil uji che-square menunjukkan ada hubungan yang signifikan antara riwayat penyakit keluarga dengan kejadian hipertensi $(p=0,001)$. Dari analisis Odds Ratio (OR) diketahui kejadian hipertensi pada riwayat penyakit keluarga kategori positif sebesar 11 kali lebih beresiko menderita hipertensi.

Berdasarkan IMT, proposi kejadian hipertensi mayoritas 28 orang pada IMT kategori tidak obesitas $(53,8 \%)$, dan minoritas 24 orang pada IMT kategori obesitas (46,2\%). Hasil uji chesquare menunjukkan ada hubungan yang signifikan antara obesitas dengan kejadian hipertensi $(p=0,044)$. Dari analisis Odds Ratio (OR) diketahui kejadian hipertensi pada obesitas 2,5 kali lebih beresiko menderita hipertensi.

Berdasarkan kebiasaan merokok, proposi kejadian hipertensi mayoritas 29 orang pada responden yang merokok $(55,8 \%)$, dan minoritas 23 orang pada kategori tidak merokok (44,2\%). Hasil uji che-square menunjukkan ada hubungan yang signifikan antara merokok dengan kejadian hipertensi $(p=0,020)$. Dari analisis Odds Ratio (OR) diketahui kejadian hipertensi pada responden yang merokok 2,8 kali lebih beresiko menderita hipertensi.

Berdasarkan kebiasaan mengkonsumsi minuman beralkohol, proposi kejadian hipertensi mayoritas 48 orang pada responden tidak mengkonsumsi minuman beralkohol $(92,3 \%)$, dan minoritas 4 orang pada kategori tidak mengkonsumsi minuman beralkohol sebanyak
$(7,7 \%)$. Hasil uji che-square menunjukkan tidak ada hubungan antara kebiasaan mengkonsumsi minuman beralkohol dengan kejadian hipertensi $(p=0,583)$. Dari analisis Odds Ratio (OR) diketahui kejadian hipertensi pada responden yang mengkonsumsi minuman beralkohol hanya 0,6 kali lebih beresiko menderita hipertensi.

Berdasarkan tingkat stress, proposi kejadian hipertensi mayoritas 43 orang pada responden yang mengalami stress $(82,7 \%)$, dan minoritas 9 orang pada kategori tidak stress sebanyak (17,3\%). Hasil uji che-square menunjukkan ada hubungan yang signifikan antara stress dengan kejadian hipertensi $(p=0,023)$. Dari analisis Odds Ratio (OR) diketahui kejadian hipertensi pada responden yang mengalami stress 3 kali lebih beresiko menderita hipertensi.

\section{Analisis Multivariat}

Analsis multivariat merupakan analisis lanjutan dari analisis bivariat dengan kriteria nilai signifikan $(p)<0,25$ dari hasil analisis bivariat. Berdasarkan tabel-tabel diatas, diketahui variabel yang masuk dalam analisis multivariat adalah variabel (1) usia, (2) jenis kelamin, (3) riwayat penyakit keluarga, (4) IMT, (5) kebiasaan merokok, (6) mengkonsumsi minuman beralkohol, dan (7) tingkat stress. Uji statistik yang digunakan dalam analisis multivariat ini adalah uji regresi linear berganda dengan pertimbangan hasil ukur variabel dependen terdiri dari dua kategori (biner), dan skala ukurnya merupakan skala ordinal, serta variabel yang akan diuji lebih dari 2 variabel, seperti pada tabel 4.4 dibawah ini:

Tabel 3 Uji Regresi Logistik Tahap I

\begin{tabular}{|c|c|c|c|c|c|c|}
\hline \multirow[b]{2}{*}{ Variabel } & \multirow[b]{2}{*}{ B } & \multirow[t]{2}{*}{ P value } & \multirow[b]{2}{*}{ df } & \multirow[b]{2}{*}{$\begin{array}{l}\text { Exp } \\
\text { (B) }\end{array}$} & \multicolumn{2}{|c|}{ 95\% C.I. for $\operatorname{Exp}(B)$} \\
\hline & & & & & Lower & Upper \\
\hline Usia & 1,766 & $0,002 *$ & 1 & 5,845 & 1,866 & 18,310 \\
\hline Jenis kelamin & $-1,089$ & $0,166 *$ & 1 & 0,337 & 0,072 & 1,571 \\
\hline Riwayat Keluarga & 2,101 & $0,066^{*}$ & 1 & 8,175 & 0,868 & 76,953 \\
\hline IMT & 0,265 & 0,658 & 1 & 1,303 & 0,404 & 4,207 \\
\hline Merokok & 0,700 & 0,265 & 1 & 2,014 & 0,589 & 6,888 \\
\hline Konsumsi alkohol & $-0,505$ & 0,545 & 1 & 0,603 & 0,118 & 3,097 \\
\hline Tingkat Stress & $-0,404$ & 0,637 & 1 & 0,668 & 0,124 & 3,581 \\
\hline Constant & $-3,940$ & 0,041 & 1 & 0,019 & & \\
\hline
\end{tabular}

Tabel 3 di atas merupakan hasil uji pertama analisis multivariat dengan uji regresi logistik diperoleh variabel yang mempunyai nilai $p<0,25$ yaitu usia $(0,002)$, jenis kelamin $(0,166)$, dan riwayat keluarga $(0,066)$. Sehingga variabelvaribel tersebut dapat dijadikan kandidat pada tahap kedua. 
Tabel 4 Uji Regresi Logistik Tahap II

\begin{tabular}{|c|c|c|c|c|c|c|}
\hline \multirow[t]{2}{*}{ Variabel } & \multirow[t]{2}{*}{ B } & \multirow[t]{2}{*}{$P$ value } & \multirow[t]{2}{*}{ df } & \multirow[t]{2}{*}{$\operatorname{Exp}(B)$} & \multicolumn{2}{|c|}{$\begin{array}{c}\text { 95\% C.I. for } \\
\operatorname{Exp(B)}\end{array}$} \\
\hline & & & & & Lower & Upper \\
\hline Usia & 1,770 & $0,002^{*}$ & 1 & 5,873 & 1,952 & 17,672 \\
\hline Jenis kelamin & $-0,965$ & 0,169 & 1 & 0,381 & 0,097 & 1,505 \\
\hline Riwayat Keluarga & 2,042 & $0,042 *$ & 1 & 70,703 & 1,077 & 55,071 \\
\hline Constant & $-3,990$ & 0,000 & 1 & 0,019 & & \\
\hline
\end{tabular}

Pada tahap kedua berdasarkan uji regresi logistik dengan menggunakan nilai signifikansi $p<$ 0,05 . Pada tabel 4 dapat diketahui bahwa variabel yang mempunyai nilai $p<0,05$ dimasukkan ke model multivariat tahap akhir yaitu usia $(p=$
$0,002)$ dengan nilai exponent $(B)=1,770$, dan riwayat keluarga $p=0,042$ dengan nilai exponent $(B)=2,042$. Sehingga kedua variabel tersebut dapat dijadikan kandidat pada tahap berikutnya.

Tabel 5 Uji Regresi Logistik Tahap Akhir

\begin{tabular}{|c|c|c|c|c|c|c|}
\hline \multirow[b]{2}{*}{ Variabel } & \multirow{2}{*}{ B } & \multirow{2}{*}{$\begin{array}{c}P \\
\text { value }\end{array}$} & \multirow[b]{2}{*}{ df } & \multirow[b]{2}{*}{$\operatorname{Exp}(B)$} & \multicolumn{2}{|c|}{ 95\% C.I. for $\operatorname{Exp(B)}$} \\
\hline & & & & & Lower & Upper \\
\hline Jsia & 1,627 & $0,002 *$ & 1 & 5,091 & 1,780 & 14,557 \\
\hline Riwayat Keluarga & 1,368 & 0,117 & 1 & 3,929 & 0,710 & 21,749 \\
\hline Constant & $-4,287$ & 0,000 & 1 & 0,014 & & \\
\hline
\end{tabular}

Setelah dilakukan pada uji regresi logistik tahap kedua yang menjadi kandidat adalah variabel usia, jenis kelamin, dan riwayat keluarga. Pada tahap akhir ini, untuk mencari variabel yang paling dominan berpengaruh terhadap kejadian hipertensi pada lansia, digunakan nilai Odds Ratio atau $\operatorname{Exp}(B)$. Berdasarkan tabel 4.6 di atas dapat diketahui bahwa dari hasil uji regresi tahap akhir, kekuatan hubungan usia dan riwayat keluarga yang paling kuat adalah usia dengan nilai $\operatorname{Exp}(\mathrm{B})$ $(5,091)$, yang artinya bahwa faktor usia 5 kali lebih berpengaruh dengan kejadian hipertensi pada lansia dibanding dengan faktor-faktor yang lain.

\section{Hubungan Usia dengan Kejadian Hipertensi}

Angka insiden hipertensi sangat tinggi terutama pada populasi lanjut usia (lansia), usia di atas 60 tahun, dengan prevalensi mencapai 60$80 \%$ dari populasi lansia. Diperkirakan 2 dari 3 lansia mengalami hipertensi (Mateos, 2012). Keadaan ini didukung oleh penelitian yang menunjukkan bahwa prevalensi hipertensi meningkat seiring dengan pertambahan usia. Pada sebuah penelitian di Sao Paulo didapatkan prevalensi hipertensi pada lansia sebesar $70 \%$ dari jumlah populasinya (Lacerdaa, 2016). Keadaan serupa juga ditemukan pada penelitian yang dilakukan di China, dimana pada penelitian tersebut hipertensi ditemukan pada $53 \%$ populasi lansia (Miao, 2015).

Hasil penelitian ini diketahui proporsi kejadian hipertensi pada responden mayoritas mengalami kejadian hipertensi pada usia $\geq 65$ tahun (76,9\%). Hasil uji che-square menunjukkan ada hubungan yang signifikan antara usia dengan kejadian hipertensi $(p=0,000)$. Dari analisis Odds Ratio (OR) diketahui Usia $\geq 65$ tahun 7,5 kali lebih beresiko menderita hipertensi.

Hasil penelitian ini sejalan dengan hasil penelitian yang dilakukan oleh Wahyuningsih (2013) dari tentang Faktor yang Mempengaruhi Hipertensi pada Usia Lanjut. Dari hasil penelitiannya dengan tabulasi silang antara faktor umur dengan kejadian hipertensi, Hasil uji statistik Chi Square didapatkan nilai $\mathrm{X}$ hitung = 8,132 pada derajat kebebasan 2 dengan taraf signifikansi 0,017 . Penelitian ini didapatkan hasil bahwa $\mathrm{p}$ hitung $0,017<0,05$ sehingga ada hubungan yang siginifikan antara umur dengan kejadian hipertensi.

Penelitian ini juga sejalan dengan hasil penelitian yang dilakukan oleh Martati (2013), dari hasil uji secara statistik dengan menggunakan uji chi-square, diperoleh nilai $p=0,041$ yang berarti secara umum terdapat hubungan yang bermakna antara umur dengan kejadian hipertensi. 
Sedangkan jika dibandingkan menurut kelompok umur 45-59 tahun dengan kelompok umur 60-74 tahun, hasil uji statistik dengan menggunakan uji chi square diperoleh nilai $p=0,012$ yang berarti terdapat hubungan yang bermakna antara umur dengan kejadian hipertensi. Rasio prevalens kejadian hipertensi pada kelompok umur 45-59 tahun dibandingkan dengan kelompok umur 6074 tahun adalah $0,734(p=0,012)$. Artinya Lansia pada kelompok umur 60-74 tahun memiliki kemungkinan resiko yang lebih besar mengalami hipertensi dibandingkan dengan Lansia pada kelompok umur 45-59 tahun.

\section{Hubungan Jenis Kelamin dengan Kejadian Hipertensi}

Berdasarkan jenis kelamin, proporsi kejadian hipertensi mayoritas pada jenis kelamin laki-laki $(71,2 \%)$, dan pada jenis kelamin perempuan yang mengalami kejadian hipertensi hanya $(28,8 \%)$. Hasil uji che-square menunjukkan tidak ada hubungan antara jenis kelamin dengan kejadian hipertensi $(p=0,212)$. Dari analisis Odds Ratio (OR) diketahui kejadian hipertensi pada lakilaki hanya 1,7 kali lebih beresiko menderita hipertensi. Tidak adanya hubungan ini dikarenakan kejadian hipertensi mayoritas pada jenis kelamin laki-laki yaitu sebanyak $71,2 \%$, dan tidak hipertensi mayoritas pada jenis kelamin lakilaki yaitu sebanyak 58,3\%. Sementara jenis kelamin perempuan paling sedikit baik yang mengalami kejadian hipertensi maupun tidak hipertensi.

Hal ini sejalan dengan hasil penelitian Arifin (2016) tentang Faktor-Faktor Yang Berhubungan Dengan Kejadian Hipertensi Pada Kelompok Lanjut Usia Di Wilayah Kerja UPT Puskesmas Petang I Kabupaten Badung. Berdasarkan hasil uji statistik menggunakan chi-square didapatkan nilai $\mathrm{p}=0,902>0,05$, artinya tidak terdapat hubungan yang bermakna antara jenis kelamin dengan kejadian hipertensi. Dapat dilihat bahwa nilai $\mathrm{RP}=0,980<1$, yang artinya jenis kelamin perempuan bukan merupakan faktor risiko untuk terjadinya hipertensi, melainkan merupakan faktor protektif. Namun dari rentang interval kepercayaan mencakup angka 1 (IK 95\% $=0,712$ sampai 1,350$)$, yang artinya pada populasi yang diwakili oleh sampel masih mungkin nilai rasio prevalensnya $=1$. Ini berarti bahwa dari data yang ada belum dapat disimpulkan bahwa faktor jenis kelamin perempuan yang dikaji benar-benar merupakan faktor protektif. Sehingga dapat disimpulkan bahwa jenis kelamin perempuan belum dapat dikatakan secara definitif sebagai faktor yang berhubungan dengan terjadinya hipertensi pada kelompok lansia di wilayah kerja Puskesmas Petang I Kabupaten Badung.

Hasil penelitian Fitriana (2015) tentang diketahui bahwa faktor jenis kelamin tidak ada hubungan yang signifikan antara jenis kelamin dengan kejadian hipertensi. Namun penelitian Yuliarti (2011), diketahui bahwa ada hubungan yang signifikan antara jenis kelamin dengan kejadian hipertensi. Hal tersebut menunjukkan bahwa kejadian hipertensi pada perempuan dipengaruhi oleh kadara hormon estrogen. Hormon estrogen tersebut akan menurun kadarnya ketika perempuan memasuki usia tua (menepouse) sehingga perempuan menjadi lebih rentan terhadap hipertensi.

Hal ini sejalan dengan penelitian yang dilakukan oleh Wahyuningsih (2013), pada tabulasi silang antara faktor jenis kelamin dengan kejadian hipertensi, hasil uji statistik Chi-Square didapatkan nilai $X$ hitung $=0,001$ pada derajat kebebasan 1 dengan taraf signifi kansi 0,979. Penelitian ini didapatkan hasil bahwa $p$ hitung $0,979>0,05$ sehingga hipotesis kerja ditolak. Kesimpulannya bahwa tidak ada hubungan antara faktor jenis kelamin dengan terjadinya hipertensi pada usia lanjut di Dusun Kabregan, Srimulyo, Piyungan, Bantul, Yogyakarta.

\section{Hubungan Riwayat Penyakit Keluarga dengan Kejadian Hipertensi}

Menurut Black dan Hawks (2005) dalam Sutanto (2010) seseorang yang mempunyai riwayat hipertensi pada keluarga akan mempunyai risiko yang lebih besar untuk mengalami hipertensi. Hal ini terjadi karena seseorang yang mempunyai riwayat keluarga hipertensi beberapa gennya akan berinteraksi dengan lingkungan dan menyebabkan peningkatan tekanan darah. Peran faktor genetik terhadap timbulnya hipertensi terbukti dengan ditemukannya kejadian bahwa hipertensi lebih banyak pada kembar monozigot (satu sel telur) dari pada heterozigot (berbeda sel telur). Seorang penderita yang mempunyai sifat genetik hipertensi primer (esensial) apabila dibiarkan secara alamiah tanpa intervensi terapi, bersama lingkungannya akan menyebabkan hipertensinya berkembang dan dalam waktu sekitar 3050 tahun akan timbul tanda dan gejala.

Hasil penelitian ini, proposi kejadian hipertensi mayoritas pada riwayat penyakit 
keluarga kategori positif $(96,2 \%)$, dan riwayat penyakit keluarga kategori negatif $(3,8 \%)$. Hasil uji che-square menunjukkan ada hubungan yang signifikan antara riwayat penyakit keluarga dengan kejadian hipertensi $(p=0,001)$.

Hasil penelitian ini sejalan dengan hasil penelitian yang dilakukan oleh Suciyati dan Adnan pada tahun 2013. Penelitian yang bertujuan untuk mengetahui prevalensi hipertensi dan faktorfaktor yang berhubungan dengan hipertensi pada lansia tersebut merupakan penelitian kuantitatif dengan desain studi cross sectional pada lansia yang terdaftar di posyandu lansia wilayah Kecamatan Johar Jakarta Pusat. Dari hasil penelitian tersebut didapatkan bahwa riwayat hipertensi pada keluarga terbukti sebagai faktor risiko terjadinya hipertensi berdasarkan hasil uji statistik yang ditunjukan dengan nilai $p<0,05$. Kemungkinan terjadinya hipertensi pada mereka yang memiliki riwayat hipertensi pada keluarga adalah sebesar 3,216 kali dibandingkan mereka yang tidak memiliki riwayat hipertensi pada keluarga.

Penelitian ini juga sejalan dengan hasil penelitian yang dilakukan oleh Sofyan (2012) tentang faktor- faktor yang berhubungan dengan kejadian hipertensi pada lansia yang berada dalam wilayah kerja Puskesmas Petang I, Berdasarkan hasil uji statistik menggunakan chisquare didapatkan nilai $p=0,019<0,05$, artinya terdapat hubungan yang bermakna antara Genetik dengan kejadian hipertensi.

Dari Tabel 4.3 juga dapat dilihat dari analisis Odds Ratio (OR) diketahui kejadian hipertensi pada riwayat penyakit keluarga kategori positif sebesar 11 kali lebih beresiko menderita hipertensi dibanding lansia yang tidak memiliki riwayat hipertensi pada keluarga. Sehingga dapat disimpulkan bahwa benar lansia yang memiliki riwayat hipertensi pada keluarga merupakan faktor yang berhubungan dengan terjadinya hipertensi pada pada kelompok lansia di Wilayah Kerja Puskesmas Simpang Bah Jambi Kabupaten Simalungun.

\section{Hubungan IMT dengan Kejadian Hipertensi}

Obesitas berkaitan dengan kegemaran mengkonsumsi makanan tinggi lemak serta meningkatkan risiko terjadinya hipertensi akibat faktor lain. Makin besar massa tubuh, akan meningkat volume darah yang dibutuhkan untuk memasok oksigen dan makanan ke jaringan tubuh. Akibatnya, dinding arteri akan mendapatkan tekanan yang lebih besar yang menyebabkan terjadinya kenaikan tekanan darah. Selain itu, kelebihan berat badan juga meningkatkan frekuensi denyut jantung (Sheldon, 2005).

Di samping itu, kondisi lain yang juga berperan adalah sistem renin-angiotensin. Sistem ini erat kaitannya dengan natrium atau garam yang dikonsumsi, yang pada penelitian ini faktor resiko tersebut tidak dievaluasi. Dalam darah renin mengubah angiotensinogen menjadi angiotensin. Angiotensin ini dapat menyebabkan diameter pembuluh darah mengecil. Sementara renin memicu produksi aldosteron, yang berfungsi untuk mengatur volume cairan ekstraseluler. Jika natrium meningkat maka aldosteron akan mengurangi pengeluaran natrium dengan cara meningkatkan reabsorbsi natrium di tubulusginjal. Hal ini menyebabkan natrium dalam darah meningkat, dimana natrium mempunyai sifat retensi air dalam pembuluh darah, sehingga menyebabkan volume darah menjadi naik dan hal itu secara otomatis menyebabkan tekanan darah meningkat (Price, 2006).

Hasil penelitian ini, proposi kejadian hipertensi mayoritas pada IMT kategori tidak obesitas $(53,8 \%)$, dan minoritas pada IMT kategori obesitas $(46,2 \%)$. Hasil uji che-square menunjukkan ada hubungan yang signifikan antara obesitas dengan kejadian hipertensi $(p=$ 0,044). Dari analisis Odds Ratio (OR) diketahui kejadian hipertensi pada obesitas 2,5 kali lebih beresiko menderita hipertensi.

Penelitian ini tidak sejalan dengan penelitian Siringoringo (2013). Pada penelitian tersebut didapatkan dari 33 responden yang obesitas, terdapat 24 responden yang menderita hipertensi. Dari Uji Statistik didapatkan $p=0,160$ $(p>0,05)$ sehingga tidak terdapat hubungan yang bermakna antara obesitas dengan kejadian hipertensi pada lansia.

Penelitian lain juga bertolak belakang dengan hasil penelitian ini, Arifin (2016) , berdasarkan hasil uji statistik menggunakan chisquare didapatkan nilai $p=0,271>0,05$, artinya tidak terdapat hubungan yang bermakna antara obesitas dengan kejadian hipertensi. Dari Tabel 5 juga dapat dilihat bahwa nilai $\mathrm{RP}=1,179>1$, yang artinya obesitas merupakan faktor risiko untuk terjadinya hipertensi. Namun dari rentang interval kepercayaan mencakup angka 1 (IK 95\% 0,882 sampai 1,574 ), yang artinya pada populasi 
yang diwakili oleh sampel masih mungkin nilai rasio prevalensnya $=1$. Ini berarti bahwa dari data yang ada belum dapat disimpulkan bahwa faktor obesitas yang dikaji benar-benar merupakan faktor risiko. Sehingga dapat disimpulkan bahwa obesitas belum dapat dikatakan secara definitif sebagai faktor yang berhubungan dengan terjadinya hipertensi pada kelompok lansia di wilayah kerja Puskesmas Petang I Kabupaten Badung.

Namun hasil penelitian ini sejalan dengan penelitian Anggara (2012) bahwa ditemukan hubungan yang bermakna antara obesitas dengan kejadian hipertensi. Tidak terdapatnya hubungan tersebut kemungkinan disebabkan karena adanya peningkatan sistem simpatis. Peningkatan sistem simpatis ini sejalan dengan hasil tabulasi silang antara obesitas dengan kejadian stres, yaitu diketahui bahwa kejadian stres lebih banyak didapatkan pada lansia yang tidak obesitas. Artinya aktivitas saraf simpatis yang mengatur fungsi saraf dan hormon dapat menyebabkan peningkatkan denyut jantung, penyempitan arteri (vasokonstriksi) serta peningkatan retensi air dan natrium (Syaifuddin, 2006).

\section{Hubungan Kebiasaan Merokok dengan Kejadian Hipertensi}

Merokok adalah kebiasaan menghisap rokok dan pernah merokok dalam kehidupan responden. Data dikategorikan menjadi dua, yaitu merokok jika saat ini responden memiliki kebiasaan merekok dan atau pernah memiliki kebiasaan merokok sebelumnya baik itu merupakan perokok ringan, perokok sedang, maupun perokok berat. Dan tidak merokok jika responden menyatakan dirinya tidak memiliki kebiasaan merekok dan atau tidak pernah memiliki kebiasaan merokok sebelumnya. Zat-zat kimia beracun seperti nikotin dan karbon monoksida yang dihisap melalui rokok yang masuk ke dalam aliran darah dapat merusak lapisan endotel pembuluh darah arteri, dan mengakibatkan proses artereosklerosis, dan tekanan darah tinggi. Pada studi autopsi, dibuktikan kaitan erat antara kebiasaan merokok dengan adanya artereosklerosis pada seluruh pembuluh darah. Merokok juga meningkatkan denyut jantung dan kebutuhan oksigen untuk disuplai ke otot-otot jantung. Merokok pada penderita tekanan darah tinggi semakin meningkatkan risiko kerusakan pada pernbuluh darah arteri.
Hasil penelitian ini bahwa proposi kejadian hipertensi mayoritas pada responden yang merokok $(55,8 \%)$, dan minoritas pada kategori tidak merokok (44,2\%). Hasil uji che-square menunjukkan ada hubungan yang signifikan antara merokok dengan kejadian hipertensi ( $p=$ 0,020). Dari analisis Odds Ratio (OR) diketahui kejadian hipertensi pada responden yang merokok 2,8 kali lebih beresiko menderita hipertensi.

Penelitian ini tidak sejalan dengan penelitian yang dilakukan oleh Fatrina Yossi pada tahun 2014. Hubungan antara merokok dengan kejadian hipertensi didapatkan dari 43 responden yang merokok, terdapat 28 responden yang menderita hipertensi. Dari Uji Statistik didapatkan $p=0,092 \leq 0,1$ sehingga terdapat hubungan yang bermakna antara kebiasaan merokok dengan kejadian hipertensi pada lanjut usia.

\section{Hubungan Kebiasaan Mengkonsumsi Minuman Beralkohol dengan Kejadian Hipertensi}

Konsumsi alkohol adalah kebiasaan/perilaku meminum alkohol dan pernah minum alkohol dalam kehidupan responden. Data dikategorikan menjadi dua, yaitu mengkonsumsi alkohol jika saat ini responden memiliki kebiasaan mengkonsumsi alkohol dan atau pernah memiliki kebiasaan mengkonsumsi alkohol sebelumnya dan tidak mengkonsumsi alkohol jika responden menyatakan dirinya tidak memiliki kebiasaan mengkonsumsi alkohol dan atau tidak pernah memiliki kebiasaan mengkonsumsi alkohol sebelumnya. Mekanisme peningkatan tekanan darah akibat alkohol masih belum jelas. Namun, diduga peningkatan kadar kortisol, dan peningkatan volume sel darah merah serta kekentalan darah berperan dalam menaikan tekanan darah. Beberapa studi menunjukkan hubungan langsung antara tekanan darah dan asupan alkohol, dan diantaranya melaporkan bahwa efek terhadap tekanan darah baru nampak apabila mengkonsumsi alkohol sekitar 2-3 gelas ukuran standar setiap harinya (Krummel, 2004).

Berdasarkan hail penelitian, kebiasaan mengkonsumsi minuman beralkohol, proposi kejadian hipertensi mayoritas pada responden tidak mengkonsumsi minuman beralkohol $(92,3 \%)$, dan minoritas pada kategori tidak mengkonsumsi minuman beralkohol sebanyak $(7,7 \%)$. Hasil uji che-square menunjukkan tidak ada hubungan antara kebiasaan mengkonsumsi minuman beralkohol dengan kejadian hipertensi 
$(p=0,583)$. Dari analisis Odds Ratio (OR) diketahui kejadian hipertensi pada responden yang mengkonsumsi minuman beralkohol hanya 0,6 kali lebih beresiko menderita hipertensi.

Hasil penelitian lain sejalan dengan penelitian yang dilakukan oleh Rachman Fauzia, dkk. pada tahun 2011 yang bertujuan untuk mengetahui berbagai faktor yang berhubungan dengan kejadian hipertensi pada lansia menyebutkan bahwa konsumsi alkohol tidak berpengaruh terhadap timbulnya faktor risiko hipertensi dengan nilai $p=0,42 ; R P=0,28$ dan $95 \% \mathrm{Cl}=0,01-5,06$. Meskipun demikian, tidak berarti bahwa konsumsi alkohol tidak berisiko hipertensi. Konsumsi secara berlebihan alkohol dan kafein yang terdapat dalam minuman kopi, teh dan kola akan meningkatkan risiko terjadinya hipertensi pada seseorang. Alkohol bersifat meningkatkan aktivitas saraf simpatis karena dapat merangsang sekresi corticotrophin releasing hormone (CRH) yang akhirnya akan meningkatkan tekanan darah.

\section{Hubungan Stress dengan Kejadian Hipertensi}

Tekanan darah tinggi atau hipertensi dapat diakibatkan oleh stres yang diderita individu, sebab reaksi yang muncul terhadap impuls stres adalah tekanan darahnya meningkat. Selain itu, umumnya individu yang mengalami stres sulit tidur, sehingga akan berdampak pada tekanan darahnya yang cenderung tinggi (Sukadiyanto, 2010). Dalam Triyanto, (2014) pun dikatakan bahwa ketidakpatuhan dalam pengobatan dan stres yang berkepanjangan dapat menambah parah hipertensi.

Hubungan antara tingkat stres dengan tekanan darah diduga melalui aktivitas saraf simpatis, yang dapat meningkatkan tekanan darah secara bertahap. Stres atau ketegangan jiwa (rasa tertekan, murung, bingung, cemas, berdebar-debar, rasa marah, dendam, rasa takut dan rasa bersalah), dapat merangsang kelenjar anak ginjal melepas hormon adrenalin dan memacu jantung berdenyut lebih cepat serta lebih kuat, sehingga tekanan darah akan meningkat (Mahendra, 2004). Penderita hipertensi yang dapat penatalaksanaan hipertensi atau tidak cenderung memiliki tekanan darah yang tinggi meski ada kalanya tekanan darah pada lansia berada dalam batas normal. Kondisi akan diperburuk dengan adanya peningkatan tekanan darah akibat stres, maka tekanan darah akan menjadi semakin tinggi. Apabila kondisi ini terus menerus dalam waktu yang lama tanpa penanganan yang tepat maka tekanan darah tinggi tersebut akan sulit dikontrol. Tekanan darah yang tidak terkontrol, akan menjadikan penyebab utama penyakit stroke (Prasetyorini, 2012).

Berdasarkan hasil penelitian, kejadian hipertensi mayoritas pada responden yang mengalami stress $(82,7 \%)$, dan minoritas pada kategori tidak stress sebanyak (17,3\%). Hasil uji che-square menunjukkan ada hubungan yang signifikan antara stress dengan kejadian hipertensi $(p=0,023)$. Dari analisis Odds Ratio (OR) diketahui kejadian hipertensi pada responden yang mengalami stress 3 kali lebih beresiko menderita hipertensi.

Hasil penelitian ini sejalan dengan hasil penelitian yang dilakukan oleh Seke (2016) tentang Hubungan Kejadian Stres Dengan Penyakit Hipertensi Pada Lansia Di Balai Penyantunan Lanjut Usia Senjah Cerah Kecamatan Mapanget Kota Manado. Berdasarkan uji statistik menggunakan fisher's diperoleh pvalue $=0,000<0.005$. Hal tersebut menunjukan bahwa terdapat hubungan yang signifikan antara kejadian stres dengan tingkat hipertensi di Balai Penyantunan Lanjut Usia Senjah Cerah Manado.

Hal ini juga sejalan dengan penelitian sebelumnya oleh Amriana (2012) dimana menunjukkan tingkat stres pada lansia di shelter Dongkelsari Desa Wukirsari Kecamatan Cangkringan Kabupaten bupaten Sleman Provinsi DIY adalah stres sedang yaitu 30 responden $(69,8 \%)$ dan kejadian hipertensi 20 responden $(46,5 \%)$. Hasil uji statistik didapatkan $\mathrm{p}$ value $=$ 0,021 yang artinya terdapat hubungan antara stres dengan kejadian hipertensi pada lansia di shelter Dongkelsari Desa Wukirsari Kecamatan Cangkringan Kabupaten Sleman Provinsi DIY.

\section{KESIMPULAN}

Berdasarkan hasil penelitian dan pembahasan di atas, maka dapat disimpulkan beberapa hal sebagai berikut:

a. Bahwa berdasarkan usia, mayoritas responden terdapat pada kelompok $\geq 65$ tahun yaitu sebanyak 51 orang $(58,0 \%)$, dengan jenis kelamin laki-laki sebanyak 58 orang $(65,9 \%)$, mayoritas mempunyai riwayat penyakit keluarga sebanyak 75 orang $(85,2)$, mayoritas IMT kategori Tidak obesitas sebanyak 55 orang $(62,5 \%)$, mayoritas 
responden tidak merokok sebanyak 48 orang $(54,5 \%)$, mayoritas tidak mengkonsumsi minuman ber-alkohol sebanyak 80 orang $(90,9 \%)$, mayoritas tingkat responden kategori stress sebanyak 65 orang $(73,9 \%)$, mayoritas responden mengalami kejadian hipertensi sebanyak 52 orang $(59,1 \%)$.

b. Dari uji analisis bivariat, diketahui bahwa tidak ada hubungan antara jenis kelamin $(0,212)$ dan kebiasaan mengkonsumsi minuman beralkohol $(p=0,583)$ dengan kejadian hipertensi pada lansia.

c. Ada hubungan yang signifikan antara usia $(p=0,000)$, jenis kelamin $(p=0,212)$, riwayat penyakit keluarga $(p=0,012)$, IMT $(p=0,044)$, merokok $(p=0,020)$, dan stress $(p=0,023)$ dengan kejadian hipertensi pada lansia.

d. Faktor yang paling berpengaruh secara signifikan dengan kejadian hipertensi pada lansia di Posyandu Lansia Wilayah Kerja Puskesmas Simpang Bahjambi Kabupaten Simalungun Tahun 2016 adalah faktor usia dengan nilai $\exp (B)=5,091$, yang artinya faktor usia 5 kali lebih berpengaruh dengan kejadian hipertensi pada lansia dibanding dengan faktor-faktor yang lainnya.

\section{DAFTAR PUSTAKA}

Anggara Dwi, F H dan Prayitno N., 2013. Faktorfaktor yang Berhubungan dengan Tekanan Darah di Puskesmas Telaga Murni Cikarang Barat. Jakarta: Program Studi Kesehatan Masyarakat STIKES MH. Thamrin. Jurnal Ilmiah Kesehatan. Vol 5 (1)

Arifin, 2016. Faktor-Faktor Yang Berhubungan Dengan Kejadian Hipertensi Pada Kelompok Lanjut Usia Di Wilayah Kerja Upt Puskesmas Petang I Kabupaten Badung. EJURNAL MEDIKA, VOL. 5 (7).

Asriati, 2014. Faktor Risiko Riwayat Keluarga, Status Gizi Dan Riwayat Diabetes Melitus Terhadap Kejadian Hipertensi Lansia Di Wilayah Kerja Puskesmas Pattingalloang

BKKBN, 2014. Menuju Lansia Paripurna. BKKBN. Jakarta

Darmojo R, 2011. Buku Ajar Geriatric (IImu Kesehatan Lanjut Usia). Edisi Ke-4. FKUI. Jakarta

Efendi, 2009. Keperawatan Kesehatan Komunitas: Teori Dan Praktek Dalam Keperawatan. Jilid 1. Salemba Medika. Jakarta
Estiningsih, 2012. Hubungan Indeks Massa Tubuh Dan Faktor Lain Dengan Kejadian Hipertensi Pada Kelompok Usia 18-44 Tahun Di Kelurahan Sukamaju Depok

Fitriana, 2015. Hubungan Antara Konsumsi Makanan dan Status Gizi dengan Kejadian Hipertensi pada Lansia (Studi di Posyandu Lansia Wilayah Kerja Puskesmas Wuluhan Kabupaten Jember). Artikel IImiah. Fakultas Kesehatan Masyarakat, Universitas Jember

Hadi \& Martono, 2010. Penatalaksanaan Hipertensi Pada Usia Lanjut. Pada M. Hadi \& P. Kris, eds. Geriatri: IImu Kesehatan Usia Lanjut. Balai Penerbit Fakultas Kedokteran Universitas Indonesia. Jakarta

Iskandar, 2010. Hipertensi Pengenalan, Pencegahan, dan Pengobatan. PT Bhuana Ilmu Populer. Jakarta

Karen, 2015. Riwayat Keluarga dan Hipertensi, Dikutip dari https://www.deherba. com/riwayat-keluarga-dan-hipertensi.html

Kartikawati, Anggi, 2008. Prevalensi dan Determinan Hipertensi pada Pasien Puskesmas di Jakarta Utara. Skripsi FKM

Kayce Bell, 2015. Hypertension: The Silent Killer: Updated JNC-8 Guideline Recommendations, Harrison School of Pharmacy, Auburn University. Alabama, United States

Kemenkes RI., 2014. Gambaran Kesehatan Lanjut Usia Di Indonesia, Kementerian Kesehatan Republik Indonesia. Jakarta

Kementerian Kesehatan, 2013. Prevalensi Hipertensi, Penyakit yang Membahayakan. Kementerian Kesehatan Republik Indonesia. Jakarta.

Kementerian Kesehatan, 2013. Hipertensi. Pada Infodatin (Pusat Data dan Informasi Kementerian Kesehatan RI). Kementerian Kesehatan Republik Indonesia. Jakarta

Kementerian Kesehatan. 2013. Riset Kesehatan Dasar. Badan Penelitian dan pengembangan Kesehatan Kementrian Kesehatan RI. Jakarta

Lacerdaa PJ et al, 2016. Descriptive study of the prevalence of anemia, hypertension, diabetes and quality of life in a randomly selected population of elderly subjects from Sao Paulo. Elsevier.

Machfoedz, 2010. Statistika Deskriptif : Bidang Kesehatan, Keperawatan dan Kebidanan (Bio Statistik). Fitramaya. Yogyakarta 
Malonda, N. S. H. 2010. Pola Makan dan Konsumsi Alkohol Sebagai Faktor Risiko Hipertensi Pada Lansia di Kota Tomohon Sulawesi Utara. Tesis. UGM. Jogjakarta.

Martati Siringo-ringo, 2013. Faktor-Faktor Yang Berhubungan Dengan Hipertensi Pada Lansia Di Desa Sigaol Simbolon Kabupaten Samosir. Jurnal Gizi, Kesehatan Reproduksi dan Epidemiologi. Vol. 2. No. 6 tahun 2013

Mateos-C'aceres PJ et II, 2012. New and Old Mechanisms Associated withHypertension in the Elderly. International Journal of Hypertension.

Medkes, 2013. Kalkulator IMT Ukur Berat Badan Ideal. Dikutip dari http://www.medkes.com/2013/11/kalkulato r-imt-ukur-berat-badan-ideal.html

Miao Liu, et al. 2015. Association Between Family History and Hypertension Among Chinese Elderly. Medicine journal. 94: h/m. 1-6.

Muhadi, 2016. JNC 8: Evidence-based Guideline Penanganan Pasien Hipertensi Dewasa. CDK-236/ vol. 43 no. 1, th. 2016

Notoatmodjo, S., 2007. Promosi Kesehatan dan IImu Perilaku. Rineka. Cipta. Jakarta

Novitaningtyas, 2014. Hubungan Karakteristik (Umur, Jenis Kelamin, Tingkat Pendidikan) dan Aktivitas Fisik Dengan Tekanan Darah Pada Lansia Di Kelurahan Makamhaji Kecamatan Kartasura Kabupaten Sukoharjo

Pangkahila, J.A., 2013. Pengaturan Pola Hidup dan Aktivitas Fisik Meningkatkan Umur Harapan Hidup. Jurnal Olahraga dan Fitnes.

Pithaloka, 2011. Faktor-Faktor Yang Berhubungan Dengan Kontrol Hipertensi Pada Lansia di Pos Pelayanan Terpadu Wilayah Kerja Puskesmas Mojosongo Boyolali. Jurnal Kesehatan, Vol. 4 (1); 201-214

Price, S. A. dan Wilson, L. M., 2012. Patofisiologi : Konsep Klinis Proses-. Proses Penyakit, Edisi 6, Vol. 1. EGC. Jakarta

Rahajeng \& Tuminah, 2009. Prevalensi Hipertensi dan Determinannya di Indonesia. Pusat Penelitian Biomedis dan Farmasi Badan Penelitian Kesehatan Departemen Kesehatan RI, Jakarta Majalah Kedokteran Indonesia, Vol. 59 (12).

Riyadi, 2011. Buku Keperawatan Medikal Bedah. Pustaka Pelajar: Yogyakarta

Rusdi, 2009. Awas! Anda Bisa Mati Cepat Akibat Hipertensi \& Diabetes. Power Books (IHDINA). Yogyakarta
Santoso, D., 2010. Membonsai Hipertensi. Temprina Medika Grafika. Surabaya

Saxena, D, P, Saxena, D, V, \& Saxena, D, Y, 2011, Bio-Social Factors Associated With Hypertension In Hilly Population Of Tehri Garhwal, Indian Journal of Community Health, Vol 23 (2). pp. 81-83

Seke, 2016. Hubungan Kejadian Stres Dengan Penyakit Hipertensi Pada Lansia Di Balai Penyantunan Lanjut Usia Senjah Cerah Kecamatan Mapanget Kota Manado. ejournal Keperawatan (e-Kp) Vol. 4 (2).

Siswanto, F.M. \& Pangkahila, A. 2014. Pelatihan Fisik Seimbang Meningkatkan Aktivitas Stem Cell Endogen Untuk Anti Penuaan. Jurnal Olahraga dan Fitnes.

Sofyan, 2012. Faktor- faktor yang berhubungan dengan kejadian hipertensi pada lansia yang berada dalam wilayah kerja Puskesmas Petang I

Sugiyono. 2013. Metode Penelitian Pendidikan (Pendekatan Kuantitatif, Kualitatif, dan $R \& D)$. Alfabeta. Bandung

Wahyuningsih, 2013. Faktor Yang Mempengaruhi Hipertensi pada Usia Lanjut. Jurnal Ners dan Kebidanan Indonesia. JNKI, Vol. 1 (3), $71-75$

WHO, 2014. Global target 6: $A$ 25\% relative reduction in the prevalence of raised blood pressure or contain the prevalence of raised blood pressure, according to national circumstances. Jenewa: World Health Organization.

WHO, 2013. A Global Brief on Hipertention, World Health Day 2013

Widian Nur, 2009. Deteksi Dini Kolesterol, Hipertensi Dan Stroke. Millestone Yogyakarta

Widyaningsih, 2016. Faktor Yang Mempengaruhi Hipertensi pada Usia Lanjut. Jurnal Ners dan Kebidanan Indonesia. JNKI, Vol. 1 (3), 71-75

Wikipedia, 2016. Minuman Beralkohol, dikutip dari https://id.wikipedia.org/wiki/Minuman bera lkohol

Yogiantoro, 2009. Hipertensi Essensial: Buku Ajar Ilmu. Penyakit Dalam. FKUI. Jakarta 